\title{
ELABORASI URGENSI DAN KONSEKUENSI ATAS KEBIJAKAN ASEAN DALAM MEMELIHARA STABILITAS KAWASAN DI LAUT CINA SELATAN SECARA KOLEKTIF
}

\author{
Endah Rantau Itasari ${ }^{\bowtie 1}$, Dewa Gede Sudika Mangku $u^{\bowtie 2}$
}

Faculty of Law Universitas Tanjungpura Pontianak ${ }^{1}$, Faculty of Law and Social Sciences Universitas Pendidikan Ganesha ${ }^{2}$

\begin{tabular}{l}
\hline Info Artikel \\
\hline Sejarah Artikel: \\
Disubmit: September \\
2020 \\
Direvisi: Oktober 2020 \\
Diterima: November \\
2020 \\
\hline Keywords: \\
South China Sea; ASEAN; \\
Code of Conduct; Urgency; \\
Consequences. \\
\hline
\end{tabular}

\begin{abstract}
Abstrak
China secara sepihak berdasarkan bukti sejarah pada tahun 2009 mengeluarkan peta resmi yang dikenal sebagai Peta Nine Dash Line untuk mengklaim Laut Cina Selatan. Konflik yang melibatkan banyak negara di Laut Cina Selatan belum berakhir atau surut. Klaim China tumpang tindih dengan pihak lain seperti Vietnam, Filipina, Malaysia, dan Brunei. Dalam membela klaimnya, China berusaha untuk mendominasi baik di wilayah sengketa dan dalam negosiasi multilateral. China juga terus meningkatkan kekuatan militernya untuk menekan negara-negara lain. Penelitian ini bertujuan untuk menganalisis strategi masing-masing negara anggota ASEAN terhadap China terkait dengan sengketa di Laut Cina Selatan (SCS) seperti apa akar dari konflik dan urgensi bahkan konsekuensi dalam merumuskan strategi solusinya. Metode penelitian yang digunakan dalam peneitian ini dilakukan dengan menggunakan metode penelitian normatif dengan mengumpulkan data sekunder studi perpustakaan yang studi ini berasal dari data sekunder.
\end{abstract}

\begin{abstract}
China based on historical evidence in 2009 has issued an official map known as Nine Dash Line Map to claimthe South China Sea. The conflict involving many countries in the South China Sea has not ended nor subsided. China's claim is overlapping with other parties such as Vietnam, Filipina, Malaysia, dan Brunei. In defending its claims, China seeks to dominate both in the dispute area and in multilateral negotiations. China also continues to increase its military power to press other countries. This research aims to analyze the strategies of each ASEAN member states towards China related to the dispute in the South China Sea (SCS) such as the root of the conflict and urgency even concequency of formulating its solution strategy. Five parties mentioned above are competing over sovereignty in certain areas of the SCS. The research methods used in this article is done using the Normative Research Methods by collecting secondary datain Library Studies which this study originated from pure secondary data.
\end{abstract}

(C) 2020 Universitas Negeri Semarang 


\section{PENDAHULUAN}

Konflik di Laut Cina Selatan merupakan salah satu ancaman yang berpotensi menimbulkan dampak negatif yang besar, dengan terganggunya stabilitas kawasan di Asia Tenggara. mengingat kawasan Laut China Selatan merupakan kawasan yang bernilai ekonomis, politik dan strategis dilihat dari posisi geografisnya yang menghubungkan Samudera Hindia dan Samudera Pasifik sebagai Jalur Pelayaran Perdagangan atau Sea Lane of Trade (SLOT) dan Jalur Komunikasi Internasional atau Sea Lane of Communication (SLOC). Di bidang perikanan, Laut China Selatan merupakan salah satu wilayah perikanan yang terkaya di dunia dan mengandung berbagai jenis ikan serta sumbersumber kekayaan mineral yang potensial. Cadangan minyak Laut China Selatan diperkirakan sebesar 7,5 Barel dan saat ini produksi minyak bumi mencapai 1,3 Juta Barel/hari. Wilayah Laut China Selatan memiliki peran dan arti geopolitik yang sangat besar karena menjadi titik temu Negara China dengan Negara tetangga-tetangganya, terutama yang berada dalam wilayah ASEAN dan meliputi masalah territorial, pertahanan serta keamanan. Dari sisi sejarah, Cina adalah negara yang sensitif dan kukuh dalam mempertahankan integritas teritorial. Cina merasa bahwa negara tersebut adalah pewaris dinasti-dinasti sebelumnya yang telah memanfaatkan kedua kepulauan di Laut Cina Selatan untuk kepentingan ekonomi, militer dan ilmu pengetahuan rakyat Tiongkok. Konflik ini bermula ketika Cina menyatakan klaim kepemilikan atas Laut Cina Selatan berdasarkan peta Nine Dash Line yang luasnya hampir meliputi keseluruhan Laut Cina Selatan.

Latar belakang sejarah dan penemuanpenemuan benda kuno seringkali dijadikan sebagai alasan bagi Cina untuk mempertahankan klaimnya atas kepemilikan Laut Cina Selatan. Hal ini yang kemudian ditindak lanjuti dengan show of force, yang cenderung menunjukkan powernya melalui aksi provokatif terhadap Negara-negara pengklaim lainnya. Seperti terlihat dalam kebijakannya sejak awal era 1970an hingga sekarang China intensif telah menunjukkan simbol-simbol kedaulatannya bahkan tidak jarang terlihat agresif dengan melakukan penyerangan terhadap Kapal-Kapal asing yang melintasi perairan Laut China Selatan guna mempertahankan sumber-sumber potensial barunya yang dapat mendukung kepentingan nasionalnya. Beberapa negara anggota Association of South East Asian Nations (ASEAN) yang terlibat konflik dengan Cina adalah Malaysia, Singapura, Vietnam, Filipina, dan Brunei Darussalam. Di lain pihak, negara-negara Asia Tenggara yang pada umumnya "negara lemah", berada dalam setidaknya beberapa opsi. Pertama, bersekutu dengan China agar tidak menjadi musuh atau kedua memperkuat diri dengan membentuk satu ikatan bersama dan menyeimbangkan China. Dengan heterogenitas yang tinggi tersebut, ASEAN masih terus menghadapi isu Laut Cina Selatan yang sampai saat ini belum memiliki jalan sepakat antarpihak yang terlibat. Posisi Laut Cina Selatan sebagai jalur perairan utama dalam kebanyakan ekspedisi laut, yang juga berada di antara negara-negara destinasi perdagangan dan memiliki potensi sumber daya minyak, menjadi daya tarik tersendiri bagi sebagian masyarakat internasional untuk turut terlibat di area tersebut. Mengingat heterogenitas ASEAN merupakan faktor yang kerap dianggap melemahkan ASEAN sebagai organisasi regional. Oleh karena itu, pengaruh heterogenitas negara anggota ASEAN dalam membentuk sikap dan strategi ASEAN secara kelembagaan guna menghadapi Tiongkok di Laut Cina Selatan menjadi hal yang menarik untuk diteliti lebih lanjut terkait seberapa efektif peran tersebut dan urgensi serta konsekuensi apa saja atas kebijakan yang akan diambil ASEAN dalam memelihara stabilitas kawasan di Laut Cina Selatan. Rumusan masalah dalam artikel ini adalah bagaimana efektivitas peran negara-negara ASEAN dalam memelihara stabilitas kawasan di Laut Cina Selatan secara kolektif? Dan bagaimana urgensi dan konsekuensi kebijakan ASEAN demi memperkuat peran strategis dalam memelihara stabilitas kawasan di Laut Cina Selatan secara kolektif?

\section{METODE}

Penelitian ini menggunakan penelitian hukum normatif yang metodenya berdasarkan pada kajian aplikasi dan relevansi dari teori-teori dalam studi Hukum Internasional. Pengumpulan 
data dilakukan dengan metode studi kepustakaan dengan mengumpulkan bahan hukum dan informasi. Penelitian ini menggunakan data sekunder dengan bahan hukum dalam penelitian yang di ambil dari studi kepustakaan yang terdiri dari bahan hukum primer, bahan hukum sekunder dan bahan non hukum. Bahan hukum primer berasal dari aturan yang memiliki kekuatan hukum mengikat seperti Piagam PBB dan Statuta Mahkamah Internasional tahun 1945, serta UNCLOS tahun 1982. Bahan hukum sekunder terdiri dari beberapa dokumen yang berkaitan dengan bahan hukum primer, seperti: Buku-buku yang berkaitan dengan sengketa internasional. Bahan hukum tersier, yaitu bahan hukum atau non-hukum yang menunjang bahan hukum primer dan bahan hukum sekunder. Bahan hukum primer dan sekunder yang dikumpulkan kemudian dilakukan evaluasi, interpretasi, dan argumentasi dengan menggunakan metode preskriptif. Penelitian hukum normatif atau kepustakaan tersebut mencakup penelitian terhadap asas-asas hukum, penelitian terhadap sistematik hukum, penelitiann terhadap taraf sinkronisasi vertikal dan horizontal, perbandingan hukum, sejarah hukum (Mamudji, S. 2011). Berdasarkan pada perumusan masalah dan tujuan dari penelitian yang merupakan penelitian yuridis normatif, maka pendekatan yang digunakan dalam penelitian ini adalah pendekatan undang-undang (statute approach), pendekatan kasus (case approach) serta pendekatan analasis (analytical approach). Berdasarkan Statuta Approach penulis akan menganalisa dan mengkritisi COC ASEAN, ASEAN Charter, dan beberapa instrument HAM lainnya baik ditingkat ASEAN maupun internasional. Case approach digunakan untuk menganalisis contoh kasus yang terjadi di ASEAN terkait pelanggaran yang terjadi di Laut Cina Selatan dan mengapa solusi memang mejadi urgensi.

\section{PEMBAHASAN}

Efektivitas peran Negara anggota ASEAN dalam konflik Laut Cina Selatan

\section{Adanya prinsip $A S E A N$ value dan $A S E A N$ way}

Kondisi keamanan di kawasan Asia

Tenggara jauh berbeda dengan wilayah regional lainya dikarenakan adanya unsur budaya yang telah terbentuk, seperti halnya yang ditunjukkan ASEAN Value dan ASEAN Way dimana budaya yang ada selalu berada pada depan ketika konflik terjadi (Vander 2007). Melihat pada Konsepsi Cooperative Security, ASEAN Value digunakan disini karena pada pemahaman cooperative security adalah adanya komunikasi, konsultasi, dan rasa saling percaya satu sama lain, dimana ancaman yang ada di maritime tidak lepas pada permasalahan kedaulatan yaitu teritorial. Perlunya pembentukan kesadaran saling percaya sangat dibutuhkan disini agar tidak ada kecurigaan dalam kerjasama. Pada permasalahan kerjasama pertahanan kelautan (maritime), ancaman kejahatan lintas batas negara yang menggunakan perairan tidak hanya pada persoalan individu tetapi merupakan persoalan bersama. ASEAN sebagai komunitas regional yang menjadi wadah bagi setiap anggotanya menjadi penting untuk meluaskan cakupan yang dapat mengkontrol keamanan wilayah maritim, seperti contoh kerjasama keamanan di perbatasan, kerjasama di wilayah perairan international, kerjasama di jalur strategis perdagangan internasional.

\section{Kendala prinsip non intervensi Negara-negara ASEAN}

Negara anggota ASEAN yang menunjukkan kecenderungan perilaku strategi pemihakan terhadap negara yang lebih kuat atau bandwagoning, yaitu Kamboja, Myanmar, dan Laos. Ketiga negara ini pada dasarnya tidak begitu terganggu dengan tindakan Tiongkok di kawasan karena tidak terlibat langsung dalam kasus sengketa. ASEAN memilki tantangannya sendiri dalam mengangkat isu Laut Cina Selatan menuju resolusi atau penyelesaian sengketa, yakni perbedaan kepentingan intra-negara ASEAN yang terlibat sengketa dan benturan terhadap prinsip non-intervensi ASEAN. Hal 
tersebut cenderung menjadi hambatan bagi ASEAN untuk mengangkat isu Laut Cina Selatan karena termasuk dalam kategori high issue (kedaulatan dan pertahanan) ( Lubis. 2020; 22).

\section{ASEAN yang tidak mengenal sistem voting dalam mengambil keputusan}

Negara anggota ASEAN yang menunjukkan kecenderungan perilaku strategi pemihakan terhadap negara yang lebih kuat atau bandwagoning, yaitu Kamboja, Myanmar, dan Laos. Ketiga negara ini pada dasarnya tidak begitu terganggu dengan tindakan China di kawasan karena tidak terlibat langsung dalam kasus sengketa. ASEAN memilki tantangannya sendiri dalam mengangkat isu Laut Cina Selatan menuju resolusi atau penyelesaian sengketa, yakni perbedaan kepentingan intra-negara ASEAN yang terlibat sengketa dan benturan terhadap prinsip non-intervensi ASEAN. Hal tersebut cenderung menjadi hambatan bagi ASEAN untuk mengangkat isu Laut Cina Selatan karena termasuk dalam kategori high issue (kedaulatan dan pertahanan) ( Lubis. 2020; 22).

\section{ASEAN yang tidak mengenal sistem voting dalam pengambilan keputusan}

Indonesia dapat mengupayakan penyelesaian penyusunan Code of Conduct (CoC) mengenai Laut China Selatan yang sudah berlarut-larut tidak pernah terselesaikan tersebut. Namun sekali lagi, hal tersebut akan sulit terwujud karena ASEAN tidak mengenal sistem voting dalam pengambilan keputusan, melainkan musyawarah mufakat. Dan sayangnya sampai saat ini, negara-negara anggota ASEAN masih belum satu suara dalam terhadap sengketa di Laut China Selatan ini, maka dari itu akan sulit untuk segera membentuk sebuah Code of Conduct di kawasan Laut China Selatan dalam waktu yang singkat (Itasari; 2015: 2).

Tidak jelasnya peran dan hasil dari masingmasing negara

Indonesia yang selalu menyatakan diri sebagai negara non-claimant dalam sengketa di Laut China Selatan ini lebih banyak menempatkan diri sebagai negara penengah yang menjadi mediator bagi pihak-pihak yang berseteru. Hal ini ditunjukkan dengan diadakannya berbagai workshop sejak 1990 hingga 2014, namun hingga hampir sampai seperempat abad tidak jelas apa hasil yang dicapai oleh Indonesia melalui mediasi tersebut (Aaron L. Connelly).

\section{Heterogenitas ASEAN dalam menyikapi Laut China Selatan}

1. Malaysia

Sementara dengan kekuatan-kekuatan regional maupun eksternal, Malaysia lebih memilih untuk pragmatis, yakni dengan tetap membangun kerja sama ekonomi dengan Tiongkok dan kerja sama militer dengan AS. Pada tahun 2009, setelah Malaysia mengukuhkan klaimnya ke Laut Cina Selatan bersama dengan Vietnam, Tiongkok dan Malaysia membentuk Join Action Plan on Strategic Cooperation yang kemudian merambah sektor ekonomi. Pada tahun tersebut memang perekonomian Malaysia sedang dalam penurunan. Sehingga dari sini terlihat bahwa pragmatisme Malaysia yang mengesampingkan isu kedaulatannya di Laut Cina Selatan demi kepentingan ekonomi. Sampai sejauh ini, tindakan Malaysia belum sampai pada tahap konflik diplomatik dengan Cina atas persaingan kedaulatan dan klaim teritorial yang dipersengketakan. Sikap Malaysia yang cenderung terlihat "lunak" disebabkan oleh adanya manfaat ekonomi yang diperoleh dari hubungan bilateral dengan Cina (Mangku; 2011; 45). Selama enam tahun berturut-turut ekonomi domestik Malaysia mengalami peningkatan signifikan atas kerja sama perdagangan dengan Cina. Malaysia cenderung menggunakan pilihan rasional sebagai landasan kebijakan keamanan di Laut Cina Selatan. Kebijakan luar negeri Malaysia diarahkan untuk menghindari konflik yang konfrontatif sekaligus bentuk diplomasi "diam-diam" (Prameswaran; 2017; 12). Oleh karena itu, Malaysia dapat dipandang sebagai aktor rasionalis dan pragmatis yang dimotivasi untuk memperoleh insentif ekonomi yang lebih besar dari Cina. Kebijakan luar negeri Malaysia cenderung mengarah pada keberlanjutan atas 
kemakmuran ekonomi dan pembangunan domestik dibandingkan dengan fokus terhadap keamanan kawasan.

\section{Laos: "land-locked country" yang rentan} pengaruh Tiongkok

Kepentingan Laos dalam isu Laut Cina Selatan sangat minim. Laos termasuk negara anggota ASEAN yang jarang bersuara. Terlepas dari pernyataan Menteri Luar Negeri Laos akan pentingnya isu Laut Cina Selatan dan pembentukan COC untuk menyelesaikan permasalahan dan menjaga perdamaian, Laos termasuk negara dengan perkembangan tertinggal di ASEAN dan membutuhkan investasi Tiongkok. Selama dua dekade terakhir, Tiongkok telah menanam investasi di Laos yang pada tahun 2011 mencapai \$3 miliar, diantaranya melalui pembangunan destinasi wisata dan pengadaan rel kereta api yang akan menghubungkan Vientiane dengan Kunming. Meski Laos belum menyatakan secara langsung mengenai dukungannya terhadap Tiongkok seperti Myanmar dan Kamboja, dengan besarnya pengaruh Tiongkok di Laos, tidak menutup kemungkinan bila Laos akan semakin tergantung pada Tiongkok dan menjadi salah satu pendukung posisinya dalam kasus sengketa Laut Cina Selatan (Mangku, 2012;23).

3. Myanmar: condong pada Tiongkok dan beban sanksi internasional

Tanpa kepentingan secara langsung di area sengketa, Myanmar pada dasarnya hanya mengikuti apa yang menjadi keputusan mayoritas dalam forum ASEAN sembari bermanuver di antara kekuatan-kekuatan besar yang berkepentingan di Laut Cina Selatan. Myanmar berada pada kubu oposisi terhadap keterlibatan AS di kawasan karena alasan sanksi ekonomi, dan dengan demikian lebih memilih untuk cenderung kepada Tiongkok. Peningkatan kerja sama militer dengan Tiongkok menjadi salah satu bukti posisi Myanmar. Pada tahun 1992, Tiongkok memberikan bantuan finansial dan teknis untuk pembangunan pangkalan angkatan laut di Pulau Hainggyi. Sebagai timbal balik, Tiongkok memperoleh akses untuk menggunakan fasilitas di pangkalan tersebut. Pada tahun 2011, posisi Myanmar diperjelas dengan pernyataan Thein Sein akan dukungannya terhadap posisi Tiongkok dalam sengketa Laut Cina Selatan saat kunjungannya ke Tiongkok.

\section{Vietnam}

Sampai sejauh ini, Vietnam berupaya untuk mempertahankan kedaulatan teritori dari ekspansi Cina dengan tiga pendekatan. Pertama, mendorong penyelesaian sengketa dalam bingkai internasional dengan melibatkan negara ekstraregional untuk menciptakan perimbangan kekuatan (balance of power) di kawasan. Kedua, menempatkan masalah sengketa dalam kerangka penyelesaian secara multilateral untuk memperoleh dukungan diplomatik. Ketiga, mengembangkan kapabilitas militer dengan tujuan untuk menangkis (deterrence) potensi konflik terbuka dengan Cina. Bahkan diantara negara-negara ASEAN, Vietnam saat ini paling vokal dalam penentangannya terhadap klaim dari kegiatan Cina. Delapan anggota ASEAN lain bahkan sebagian besar tetap melakukannaksi diam. Bahkan ketika mengeluarkan pernyataan, komentar lebih difokuskan pada pentingnya menghindari konflik dan menjaga stabilitas regional.

\section{Indonesia}

Sejak munculnya konflik kepemilikan atas Laut Cina Selatan, Indonesia selalu bertindak sebagai penengah bagi negara-negara yang berkonflik atas kawasan tersebut. Namun saat ini Indonesia mulai ikut terseret dalam pusaran konflik di Laut Cina Selatan ketika Cina mulai memasukkan wilayah Natuna ke dalam peta Nine Dash Line. Indonesia memiliki kepentingan atas perairan yuridiksi di utara Kepulauan Natuna yang merupakan bagian dari perairan Laut China Selatan dimana batas maritim perairan tersebut beririsan dengan klaim 9 dashed line RRC.

Kepentingan Indonesia tersebut berupa kepemilikan atas perairan Zona Ekonomi Eksklusif dan landas kontinen di laut utara Kepulauan Natuna. Situasi semakin memburuk ketika nelayan-nelayan Cina mulai masuk ke wilayah Indonesia dan melakukan Illegal Fishing di dalam Zona Ekonomi Eksklusif Indonesia. Bahkan sumber daya alam menjadi ancaman, 
dalam kontes ini tidak hanya merujuk pada energi; gas dan minyak bumi khususnya di wilayah perairan Natuna, namun juga menyangkut segala sumber daya maritim Indonesia yang terancam karena klaim Tiongkok di wilayah Laut Cina Selatan satu paket dengan klaim china's traditional fishing ground yang menyentuh ZEEI di Natuna (Wijanarko). Indonesia juga mempersepsikan Laut Cina Selatan sebagai SLOC karena merupakan jalur utama yang menghubungkan ekonomi dunia (Timur ke Barat dan sebaliknya). Sebagai salah satu pengguna jalur tersebut tentu Indonesia merasakan dampak yang signifikan terhadap perekonomiannya apabila terdapat sengketa atau konflik yang membatasi atau bahkan menutup Laut Cina Selatan (Lubis. 2020; 45).

\section{Brunei Darussalam}

Brunei Darussalam merupakan negara penuntut yang tidak terlalu intensif dalam merespons sengketa Laut Cina Selatan. Adapun alasan mengapa Brunei cenderung defensif terhadap Cina adalah akibat kondisi domestik yang sedang mengalami resesi ekonomi. Negara ini dapat dikatakan ragu-ragu dalam merespons masalah Laut Cina Selatan, mengingat Cina terus melakukan upaya diplomatik secara bilateral kepada Kesultanan Brunei agar merelakan wilayah yang dipersengketakan. Salah satu upaya Cina untuk mempengaruhi posisi dan sikap luar negeri Brunei terhadap wilayah sengketa adalah dengan cara menawarkan insentif-insentif ekonomi untuk memulihkan kondisi ekonomi domestik sekaligus menciptakan ketergantungan ekonomi Brunei Darussalam. Mengingat selama ini, Tiongkok bukan hanya konsumen utama dan pemilik teknologi pengeboran lepas pantai, namun juga pasar potensial bagi Brunei sebagai alternatif sumber pendapatan yang bergantung pada hidrokarbon. Kesultanan Brunei meyakini bahwa kesediaannya untuk tunduk terhadap kehendak di wilayah Laut Cina Selatan justru dianggap dapat mendukung pemulihan ekonomi dan diversifikasi, mendorong pertumbuhan dan pada gilirannya legitimasi politik pemerintahan dalam negeri.

Sebagai negara kecil dalam kelompok penuntut, Brunei relatif menggunakan kekuatan lunak (soft power) dalam mengajukan klaim wilayah dan lebih berorientasi pada penguatan kerja sama ekonomi berdasarkan nilai persahabatan, kepercayaan dan kehendak politik yang baik antara keduanya. Pada kenyataannya, Brunei telah sepakat untuk menjalin kemitraan strategis di bidang ekonomi dan pembangunan serta cenderung mengabaikan masalah yang dihadapi bersama dengan negara penuntut di dalam organisasi ASEAN. Upaya Cina ini, secara tidak langsung berpengaruh terhadap pelemahan sikap politik luar Brunei Darussalam dalam masalah Laut Cina Selatan. Konsekuensinya, ASEAN akan menghadapi kesulitan untuk menghasilkan konsensus bersama atas ekspansi Cina di Laut Cina Selatan. Sehingga Brunei Darussalam adalah pihak yang paling pasif di antara negara pengklaim lainnya. Brunei tidak berusaha menunjukkan kekuatan militernya di area sengketa. Hubungan bilateral yang erat membuat negara ini tidak menerapkan kebijakan konfrontatif terhadap Tiongkok.

\section{Kamboja}

Kamboja memilih untuk menghindari kebijakan konfrontatif. Dalam pembahasan sengketa Laut Cina Selatan, Kamboja yang tidak punya kepentingan secara langsung lebih sering mengikuti suara mayoritas dan jarang mengemukakan pendapatnya. Meski pada tahun 2002 Kamboja sebagai ketua ASEAN memiliki prestasi dalam mempersuasi Tiongkok untuk menyepakati DOC, namun pada edisi tahun 2012, perhatian Kamboja mengenai isu LTS cenderung menurun (Heng, 2013: 12). Keputusan Kamboja yang tidak mengagendakan isu LTS pada pertemuan puncak ASEAN di bulan April 2012 mengundang reaksi beragam dan memunculkan prasangka bahwa Kamboja memihak dan menjadi boneka Tiongkok. Menurut Vietnam, isu LTS terlalu penting untuk tidak diagendakan dalam pertemuan puncak ASEAN. Kamboja bahkan menekankan bahwa pemimpin ASEAN telah menyepakati untuk menolak internasionalisasi konflik, yang mana diketahui bahwa keputusan tersebut tidak berdasarkan konsensus. 
Faktor penyebab heterogenitas ASEAN yang kontadiktif satu sama lain

Adapun alasan tentang keterkaitan antara perbedaan sikap masing-masing anggota ASEAN dengan kolektivitas ASEAN dipengaruhi oleh dua hal. Pertama, kontradiksi yang disebabkan oleh perubahan persepsi ancaman di kawasan yang bersifat dinamis. Kedua, masing-masing negara yang telah memperoleh manfaat ekonomi dari Cina lebih memilih untuk menempuh kebijakan luar negeri yang cenderung kooperatif. Konsekuensinya, perbedaan persepsi ancaman dalam merumuskan pilihan kebijakan antara negara anggota ASEAN menimbulkan masalah ketidakseimbangan dalam mengelola akses dan pengelolaan terhadap sumber-sumber produksi di Laut Cina Selatan. Kesenjangan dalam memandang tindakan Cina memunculkan kontradiksi di dalam tubuh ASEAN sendiri untuk mengambil keputusan kolektif. Bahkan, konflik dan persaingan di Laut Cina Selatan secara perlahan telah mendorong sebagian negara ASEAN yang berkepentingan untuk meningkatkan anggaran pertahanan dalam usaha melakukan modernisasi militer masingmasing. Pada gilirannya, konflik kepentingan menyebabkan peningkatan postur militer antarnegara di kawasan. Meskipun persaingan kekuatan militer untuk memperoleh hak kedaulatan teritori dan akses sumber produksi dapat dikatakan sebagai strategi defensif untuk menyeimbangkan kekuatan hegemonik, namun sebaliknya justru menimbulkan dilemma bagi keamanan dan stabilitas kawasan. Persaingan dan pamer kekuatan pertahanan antara negara penuntut yang tergabung dalam ASEAN dan kekuatan ekstraregional menjadi tidak terelakkan.

Urgensi ASEAN dalam memelihara stabilitas kawasan di Laut Cina Selatan

Kepentingan hukum negara-negara ASEAN di Laut Cina Selatan

Laut Cina Selatan merupakan jantung geopolitik dan geoekonomi bagi banyak negara, maka setiap gejala perubahan politik internasional dan munculnya ancaman akan berpengaruh terhadap ASEAN. Dalam konteks sengketa Laut Cina Selatan, terdapat empat negara anggota ASEAN yang berkepentingan di antaranya: Vietnam, Malaysia, Brunei Darussalam, Filipina, termasuk Indonesia. Negara-negara ini terbagi ke dalam kelompok negara penuntut dan bukan penuntut, namun tetap dinilai memiliki kepentingan. Berdasarkan perspektif tradisional, semua negara yang terlibat dalam sengketa Laut Cina Selatan memiliki kesamaan tujuan nasional, yaitu untuk mengamankan kedaulatan teritorial dan memperoleh sumber produksi bagi pertumbuhan dan kepentingan ekonomi domestik.

\section{Ancaman China di Laut Cina Selatan peralatan militer yang kuat}

Berdasarkan globalfirepower.com, kekuatan militer China secara keseluruhan berada di peringkat 3 dunia. Di bawah Amerika Serikat dan Rusia, di atas India dan Prancis. Armada laut China terdiri dari 714 kapal. Terdiri dari 1 kapal induk, 52 fregat, 33 kapal perusak, 41 korvet, 76 kapal selam serta 192 kapal patroli. Ada 33 pangkalan laut yang digunakan. Jika perang di darat, China ditunjang 13 ribu tank, 40 kendaraan lapis baja, 2 ribu roket proyektor, 4 ribu artileri otomatis, dan 6.246 artileri manual. China memiliki 2,6 juta personel militer yang terdiri dari 2,1 juta aktif dan 510 ribu personel cadangan. Sebanyak 621 juta penduduknya siap perang jika kondisi mengharuskan (CNN. 2020). Hingga sekarang China intensif telah menunjukkan symbol-simbol kedaulatannya bahkan tidak jarang terlihat agresif dengan melakukan penyerangan terhadap Kapal-Kapal asing yang melintasi perairan Laut China Selatan guna mempertahankan sumber-sumber potensial barunya yang dapat mendukung kepentingan nasionalnya (http://ejournal.unisri.ac.id). Jika melihat dari sudut pandang strategis, sikap Republik Rakyat China yang semakin hari semakin agressive dalam kasus sengketa Laut China Selatan merupakan ancaman bagi negaranegara di Asia khususnya adalah negara-negara di kawasan Asia Tenggara yang bersinggungan langsung dengan Laut China Selatan.

Terutama jika melihat persaingan antara Amerika Serikat dan Republik Rakyat China di 
Laut China Selatan. Terlebih Russia yang merupakan seteru utama Amerika Serikat sejak perang dingin turut menyokong posisi Republik Rakyat China di Laut China Selatan ini. Bahkan kedua negara sudah melakukan latihan militer bersama di Laut China Selatan yang diberi nama "Joint Sea-2016". Dengan adanya latihan militer skala besar di laut seperti itu, apalagi sampai melintasi laut Indonesia dan beberapa negara sengketa dengan membawa peralatan tercanggihnya, Pemerintah China seolah ingin menunjukkan hegemoninya kepada negaranegara ASEAN dan kepada militer Amerika Serikat di wilayah tersebut bahwasanya Republik Rakyat China serius dalam mempertahankan klaimnya terhadap 9 Dash Line dan akan tetap pada posisinya untuk menolak tunduk kepada putusan hukum Permanent Court of Arbitration. Terlepas dari manuver ini adalah sebuah latihan biasa atau tidak, namun pengerahan armada laut Republik Rakyat China melewati batas Zona Ekonomi Ekslusif negaranya ditambah lagi dengan adanya pembangunan pangkalan militer di wilayah yang bukan merupakan miliknya jelas merupakan bentuk pelanggaran terhadap yurisdiksi hukum internasional.

\section{Sikap keras untuk tidak menaati putusan sidang Mahkamah Arbitrase Internasional}

China berpotensi melakukan berbagai pelanggaran dikarenakan China tidak mengakui Putusan Sidang Mahkamah Arbitrase Internasional (Permanent Court of Arbitration/ PCA) tahun 2016 soal Laut China Selatan yang diajukan Filipina. Mahkamah Arbitrase menyatakan China tidak memiliki dasar hukum untuk mengklaim wilayah perairan di Laut China Selatan. Namun pemerintah China tidak menerima putusan tersebut. Hal ini tentunya bertentangan dengan semangat mengenai peacefull rise yang sempat digadang-gadang oleh Xi Jinping pada masa awal kebangkitan Republik Rakyat China karena saat ini justru perkembangan angkatan laut Republik Rakyat China sudah sampai ke tahap yang mengkawatirkan bagi negara-negara di sekitarnya. Berdasarkan fakta yang ada, sikap yang ditunjukkan para penguasa Republik
Rakyat China menyiratkan bahwa mereka lebih condong mempersiapkan sebuah proyeksi kekuatannya secara ekonomi, perdagangan, dan militer ketimbang mencari peluang untuk melakukan kerjasama yang saling menguntungkan. Ancaman ini semakin nyata dengan adanya klaim bahwa wilayah yang dimasuki nelayan tersebut yang notabene adalah Zona Ekonomi Ekslusif Indonesia di Natuna dianggap masih sebagai wilayah Traditional Fishing Ground oleh Republik Rakyat China. Bahkan apa yang dilakukan oleh China salah satunya seperti melakukan ekspansi ke wilayah berdaulat Indonesia yakni Pulau Natuna adalah bagian dari upaya tindakan negara China untuk menunjukkan kepada dunia positive occupation terhadap wilayah maritim di Laut China Selatan.

\section{Two level game dari Cina}

Pemerintah China jelas sedang melaksanakan Two Level Game dalam sengketa di Laut China Selatan ini. Disatu sisi, China jelas tidak ingin terlihat lemah dihadapan masyarakatnya yang mengidamkan kebangkitan pasca era penghinaan, disisi yang lain China juga tidak ingin terlihat lemah dihadapan negaranegara sekitarnya maka dari itu berbagai perundingan yang diadakan seringkali berakhir buntu. Dengan sikap Pemerintah China yang terus menolak untuk bernegosiasi secara multilateral dengan negaranegara ASEAN menujukkan bahwa mereka tidak ingin di intimidasi oleh Balancing Coalition yang sedang coba dibangun oleh ASEAN dan lebih memilih berhubungan secara bilateral dengan negaranegara yang bersengketa dengannya. Hal ini sudah terbukti ampuh dalam memecah suara negara-negara anggota ASEAN. Maka dari itu, negara-negara ASEAN harus selalu waspada terhadap langkah-langkah yang dilakukan oleh Pemerintah China baik secara diplomatis maupun militer karena pada dasarnya Laut China Selatan merupakan core-interest Pemerintah China, sehingga Laut Natuna yang secara geografis terletak di Laut China Selatan harus mendapat perhatian yang lebih serius. 


\section{Doktrinisasi atas kekuasaan Cina}

Status Cina sebagai negara besar membuat negara sekitar kawasan relatif lunak terhadap tindakan Cina. Bagaimanapun juga, strategi kebijakan luar negeri Cina sejauh ini dapat dikatakan mampu menjinakkan solidaritas ASEAN. Strategi Cina untuk menginisiasi pertumbuhan ekonomi melalui pendekatan bilateral dalam bentuk inisiatif Belt and Road kepada sejumlah negara anggota ASEAN menjadi faktor yang menyebabkan pelemahan kekuatan kolektif ASEAN dalam membendung ekspansi Cina. Tantangan untuk menghasilkan konsensus bersama bagi ASEAN memerlukan kekuatan kolektif untuk mencegah perpecahan internal dan ancaman eksternal (Leifer, M. 1996; 12). Meskipun ASEAN mempunyai kebanggan dengan mempraktekan diplomasi ASEAN Way, namun sejauh ini, belum menunjukkan sikap satu suara dalam mengelola stabilitas keamanan Laut Cina Selatan (Noor, E. 2017;56). Pada kenyataannya, Cina masih terus membangun pulau buatan sekaligus mengerahkan armada militer di wilayah yang dipersengketakan dan ASEAN belum mampu mengambil sikap politik yang tegas terhadap ekspansi Cina secara kolektif.

\section{Faktor internal (ego) yang mendominasi perilaku Cina}

Sumber konsepsi ego yang berakar dari konteks domestik memiliki pengaruh yang besar dalam membentuk kebijakan luar negeri Cina di lautan. Dalam hal ini yang terjadi di Cina adalah karena faktor kebutuhan ekonomi, kapabilitas militer dan kebutuhan akan kontrol politik domestik.

\section{Kebutuhan ekonomi}

Pertama, Tiongkok ingin meningkatkan pendapatan ekonomi nasional dengan mengambil sumber daya yang ada di Laut Cina Selatan. Pada tahun 1990, Perdana Menteri Li Peng telah menyatakan bahwa Tiongkok bersedia untuk bekerja sama mengembangkan Kep. Spratly demi meningkatkan pendapatan ekonomi nasional. Pada tahun 2012, hal yang sejalan dinyatakan oleh Presiden $\mathrm{Hu}$ Jintao yang menyatakan bahwa Tiongkok harus meningkatkan kapasitas untuk mengeksplorasi sumber daya laut yang ada menjaga kepentingan dan hak teritorial. Menurut perkiraan Tiongkok, Laut Cina Selatan memiliki kandungan minyak sekitar 105-213 miliar barrel. Perkiraan tersebut beberapa kali lipat lebih banyak dari perkiraan U.S. Geological Survey yang menyebut angka 28 miliar barrel (Weatherbee, 2005)

\section{Kebutuhan membangun proyek maritime}

Kedua, Tiongkok memiliki kebutuhan untuk membangun proyek jalur sutra maritim yang memasukkan Laut Cina Selatan sebagai jalur pelayaran utama. Hal ini juga berkaitan dengan kepentingan Tiongkok mengamankan pasokan minyak di masa depan. Selama ini, keamanan jalur pengiriman minyak merupakan isu utama keamanan energi Tiongkok (Evan S. Medeiros;2009). Pelayaran jalur sutra tersebut melewati Samudera Hindia, masuk ke Selat Malaka, kemudian melalui Laut Cina Selatan. Selama ini, jumlah kapal yang melewati jalur Laut Cina Selatan sekitar lebih dari 40.000 kapal setiap tahunnya. Di antara jumlah itu, lebih dari separuh kapal supertanker dan kapal niaga di seluruh dunia melewati perairan Laut Cina Selatan (Bambang Cipto;2007;205). Dengan menguasai kawasan ini, suatu Cina tentu akan memiliki kekuasaan dan posisi yang jauh lebih luas dan kuat.

\section{Ketiga kapabilitas militer}

Tiongkok memiliki kepercayaan diri yang tinggi akan kemampuan armada militernya, seperti yang dikatakan Laksamana Huang Jiaxang dari Armada Laut Tiongkok Selatan: "We have the confidence and we have the ability to protect our interests in the South China Sea." Yang bisa dilihat dari dua hal. Pertama, mengenai anggaran belanja militer. Dalam sejarahnya, Tiongkok sama sekali tidak pernah mengendurkan kekuatan militernya. Hal itu ditunjukkan dengan anggaran militer Tiongkok yang terus mengalami peningkatan. Kedua, peningkatan kapabilitas melalui modernisasi militer PLAN. Hal ini merupakan implikasi dari peningkatan anggaran militer Tiongkok dari 
tahun ke tahun. Pada era yang baru, Tiongkok fokus pada teknologi tinggi dan pengembangan kualitas peralatan militer, misalnya senjata nuklir (Franz-Stefan Gady).

\section{Upaya yang dapat ditempuh oleh ASEAN Demi} memelihara stabilitas kawasan

Penyelesaian secara Hukum dan upaya Politik serta Diplomatik melalui ASEAN frame work merupakan cara yang paling tepat saat ini untuk sengketa di LCS, karena semangat kerja sama dan prinsip ASEAN untuk sengketa LCS ialah tidak menjadikan aksi saling mengklaim itu sebagai ajang rivalitas dan saling menghantam antar beberapa kekuatan, namun harus dicarikan solusi damai yang mengikat bagi semua pihak. Oleh karena itu kerangka ASEAN dalam penyelesaian sengketa LCS harus tetap mengedepankan langkah- langkah sbb: Secara Hukum. Sengketa LCS sebenarnya murni masalah hukum dan seyogyanya solusi masalahnya secara hukum juga. PBB sebenarnya sudah mempunyai UNCLOS 1982 sebagai landasan penyelesaian sengketa LCS, namun disadari penyelesaian sengketa lewat metode ini bukanlah hal yang mudah, karena akan menyangkut prinsip kedaulatan negara masing masing pihak yang bertikai. Solusi hukum sengketa ini memerlukan komitmen yang kuat tentang pentingnya penyelesaian masalah sengketa oleh kedua belah pihak, terutama China. Karena China adalah salah satu anggota tetap Dewan Keamanan PBB bagian dari 4 anggota tetap.

\section{Konsekuensi ASEAN dalam upaya memelihara stabilitas kawasan di Laut Cina Selatan}

Negara-negara ASEAN harus bersiap menghadapi segala kemungkinan yang terjadi, terlebih kemungkinan terjadinya konfrontasi militer, karena berdasarkan data yang ada Pemerintah China telah secara signifikan meningkatkan anggaran pertahanannya sejak tahun 2005 dan terus meningkat drastis. Tentunya hal ini patut menjadi kewaspadaan bagi negara-negara di Mulai dari pembangunan pangkalan militer di wilayah Laut China Selatan hingga mengecam tindakan Singapura yang menyediakan berbagai fasilitas pangkalan militer bagi Amerika Serikat.

Pertumbuhan anggaran pertahanan yang meningkat 2 kali lipat dalam jangka waktu 5 tahun sejak 2010 hingga 2015 hingga menyentuh angka 214,8 Miliar USD menujukkan bahwa Pemerintah China memang serius ingin membangun armada militer yang kuat. Seluruh norma dan nilai yang dianggap universal dalam dunia internasional ditentang oleh Pemerintah China secara sepihak. Logika yang digunakan oleh Pemerintah China adalah semua yang berkaitan dengan "hak sejarah" tidak bisa digugat, dan setiap negara harus menerima kebesaran Republik Rakyat China sebagai sesuatu yang tak terbantahkan.

Maka dari itu, meskipun tidak mengharapkan terjadinya konfrontasi bersenjata, negara-negara ASEAN juga harus terus meningkatkan kewaspadaannya dan kekuatan pertahanannya. Karena tidak ada yang dapat memastikan apa yang akan terjadi di kawasan Laut China Selatan. Negara-negara ASEAN juga tidak dapat menunggu Tiongkok mengikuti presedur dan aturan hukum laut internasional (UNCLOS 1982) mengingat sebagaimana negara great powers lainnya, Tiongkok akan memilah rezim internasional mana yang perlu dipatuhi berdasarkan kepentingannya. Dalam isu ini, relevansi penggunaan diplomasi pertahanan karena isu ini termasuk dalam kategori isu pertahanan dan keamanan, yang ditandai dengan adanya tindakan-tindakan asertif Tiongkok dalam penempatan militernya di pulau-pulau buatannya di Laut Cina Selatan. Selain itu respon beberapa negara, khsususnya Amerika Serikat (AS) yang meningkatkan anggaran pertahanan dan berfokus pada Asia Pasifik merupakan bentuk deterrence dan menciptakan dilema keamanan (security dilema) terhadap negaranegara di kawasan tersebut.

\section{SIMPULAN}

Tidak dapat dipungkiri bahwa setiap Negara mempunyai kepentingan tersendiri dalam hal-ekonomi, politik dan kepentingan nasional mereka, tetapi untuk menjaga stabilnya kawasan, peningkatan pertahanan wajib 
dibentuk bersama. Karena menyangkut kelancaran masing-masing kepentingan yang hendak dicapai, serta keuntungan (benefit) yang didapat. Lebih lagi mencakup lancarnya komunisasi antar negara, kelancaran ekonomi, dan dapat mendekatkan hubungan secara bilateral maupun multilateral. Dalam kasus sengketa Laut Cina Selatan, perbedaan strategi yang dipilih masing-masing negara anggota ASEAN dalam menghadapi Tiongkok memiliki peranannya masing-masing. Oleh karena itu, dapat disimpulkan bahwa, ketidakmampuan ASEAN untuk mengambil kebijakan kolektif dalam merespons sengketa Laut Cina Selatan dihadapkan pada dua keterbatasan. Pertama, persepsi terhadap lingkungan eksternal yang meliputi nilai, sistem keyakinan dan kognisi masing-masing negara anggota ASEAN. Kedua, pengaruh ekonomi-politik yang bersumber dari kekuatan ekstra-regional terhadap masingmasing anggota ASEAN. Agenda integrasi ASEAN yang menjunjung tinggi otonomi organisasi dengan cara memelihara hubungannya dengan kekuatan eksternal dan mempertahankan netralitasnya secara kolektif menjadi tantangan terbesar untuk mewujudkan integrasi yang solid demi memelihara stabilitas politik-keamanan dan perdamaian kawasan.

Pemerintah setiap negara di ASEAN hendaknya mengambil sikap dan kebijakan, mengingat permasalahan wilayah maritim tersebut sangat kompleks, maka pemerintah tiaptiap negara ASEAN wajib menjaga hubungan baik satu sama lain baik dengan negara-negara pengklaim dan non-pengklaim dan tetap menjaga stabilitas keamanan regional di Wilayah Laut China Selatan. Mengenai tindakan yang harus diambil negara ASEAN dari perspektif keamanan, maka ASEAN dapat berupaya mempercepat penyelesaian Code of Conduct (COC) di Laut Cina Selatan antara Angkatan Laut ASEAN dengan Angkatan Laut Cina. Dengan berlakunya COC, maka masing-masing Angkatan Laut menerapkan mekanisme pencegahan konflik di laut. Mekanisme COC ini sangat penting untuk meredam eskalasi konflik untuk tidak meningkat menjadi perang. Pihak yang berkepentingan dengan COC juga bisa lebih dibuka tidak hanya antar-Angkatan Laut, tapi juga bisa antar-Coast Guard. Jadi, kapal-kapal perang, kapal-kapal Coast Guard, dan pesawat tempur masing-masing negara ASEAN dan Cina semuanya menghormati COC. Pemerintah harus mengkaji secara berlanjut perkembangan situasi sengketa Laut China Selatan dan menyiapkan agenda penyelesaian permasalahan yang terjadi melalui jalur hukum maupun membicarakannya melalui forum-forum bilateral dan multilateral yang telah ada. Kementerian Luar Negeri masing-masing negara ASEAN agar segera mengagendakan kembali perundinganperundingan batas-batas laut untuk memperkuat posisi dalam mempertahankan hak berdaulat di laut Cina Selatan. Selain itu pemerintah harus mengantisipasi penyelesaian masalah secara hukum, yang berdasarkan pada perundangundangan nasional masing-masing negara, perjanjian bilateral serta multilateral yang berdasar hukum internasional.

\section{DAFTAR PUSTAKA}

B. Wijanarko. (2016). Perspektif Indonesia terhadap Overlapping Claim Zona Ekonomi Esklusif di Natuna dengan Nine Dash Lines China, Tesis Universitas Pertahanan.

Bambang Cipto (2007). Hubungan Internasional di Asia Tenggara (hlm. 205). Yogyakarta: Pustaka Pelajar.

CNN. (2020). Laut Cina Selatan Memanas: ASEAN Memilih Diplomasi, Berikut Kekuatan Militer Indonesia dan Cina Diakses dari https://www.cnnindonesia.com/nasional /20200103174155-20-462240/natunamemanas-berikut-kekuatan-militerindonesia-dan-china, pada tanggal

Donald E. Weatherbee. (2005). International Relations in Southeast Asia The Struggle for Autonomy (hlm. 134). Lanham: Rowman \& Littlefield Publishers, Inc.

Evan S. Medeiros. (2009). China's International Behavior: Activism, Opportunism, and Diversification Santa Monica: RAND Corporation. 
Itasari, E. R. (2015). Memaksimalkan Peran Treaty of Amity and Cooperation in Southeast Asia 1976 (TAC) Dalam Penyelesaian Sengketa di ASEAN. Jurnal Komunikasi Hukum (JKH), 1(1).

Kooi, Joel Vander. 2007, "The ASeAN enhanced Dispute Settlemet Mechanism: Doingitthe ASEAN Way". Dalam NewYork International Law Review. 20 N.Y. Int'1 L. Rev. 1

Leifer, M. 1996. The ASEAN Regional Forum. London: Oxford University Press

Mangku, D. G. S. (2011). Peluang dan Tantangan ASEAN Dalam Penyelesaian Sengketa Kuil Preah Vihear Di Perbatasan Kamboja dan Thailand. Pandecta: Research Law Journal, 6(2).

Mangku, D. G. S. (2012). Suatu Kajian Umum tentang Penyelesaian Sengketa Internasional Termasuk di Dalam Tubuh ASEAN. Perspektif, 17(3).

Noor, E. 2017. The South China Sea Dispute: Option for Malaysia. The South China Sea Dispute: Navigating Diplomatic and Strategic Tension. Storey, I. \& Lin, C. Y. Singapore: ISEAS-Yusof Ishak Institute

Prameswaran, P. 2017. The Truth About China's Indonesia South China Sea Tantrum. Diakses dari: https://thediplomat.com/2017/09/thetruthabout-chinas-indonesia-south-chinasea-tantrum/, pada tanggal 03 Juni 2020, pukul 08.14 WIB
Purwendah, E., Mangku, D., \& Periani, A. (2019, May). Dispute Settlements of Oil Spills in the Sea Towards Sea Environment Pollution. In First International Conference on Progressive Civil Society (ICONPROCS 2019). Atlantis Press.

Reza Lubis. 2020. Diplomasi Pertahanan Indonesia melalui ASEAN dalam Menghadapi Polemik Laut Cina Selatan. Diakses dari https://teritorial.com/opini/diplomasipertahanan-indonesia-melalui-aseandalam-menghadapi-polemik-laut-cinaselatan/, pada tanggal 04 Juni 2020, pukul 17.25 WIB.

Sarith, Heng, (2013). "A Job Well Done: Cambodia as ASEAN Chair in 2012" [online]. http://www.eastasiaforum.org/2013/01/ 19/a-job-welldone-cambodia-as-aseanchair-in-2012/, pada tanggal 01 Juni 2020, pukul 18.31 WIB

Soekanto, S., \& Mamudji, S. (2011). Penelitian Hukum Normatif Suatu Tinjauan Singkat, Jakarta: PT Raja Grafindo Persada.

Wiratmaja, I. G. N. A., Mangku, D. G. S., \& Yuliartini, N. P. R. (2020). Penyelesaian Sengketa Maritime Boundary Delimitation Di Laut Karibia Dan Samudera Pasifik Antara Costa Rica Dan Nicaragua Melalui Mahkamah Internasional. Jurnal Komunitas Yustisia, 2(1), 60-69. 